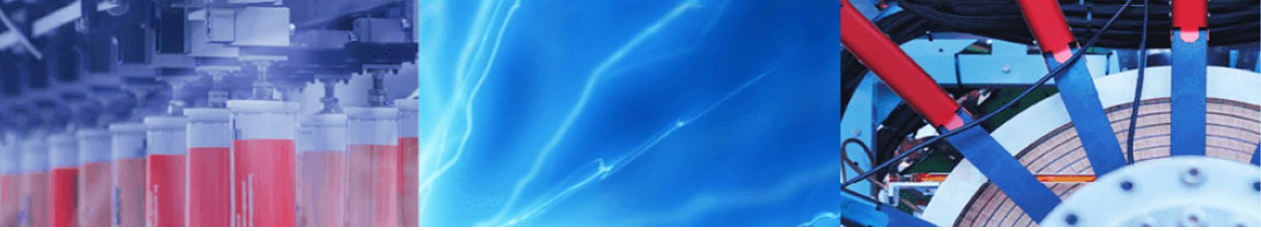

Research Article

\title{
Rainfall variability and socio-economic constraints on livestock production in the Ngorongoro Conservation Area, Tanzania
}

\author{
Cecilia M. Leweri ${ }^{1,2}$ (D) Maurus J. Msuha ${ }^{3} \cdot$ Anna C. Treydte ${ }^{1,4}$
}

Received: 22 October 2020 / Accepted: 29 December 2020 / Published online: 12 January 2021

(c) The Author(s) 2021 OPEN

\begin{abstract}
Rainfall variability is of great importance in East Africa, where small-scale farmers and pastoralists dominate. Their livestock production activities are heavily dependent on rainfall. We assessed pastoralist perceptions on climate change, particularly rainfall variability, its impact on livestock production, and the adaptive capacity of pastoralists in the Ngorongoro Conservation Area (NCA), Tanzania. We combined 241 household interviews and information from 52 participants of Participatory Rural Appraisal (PRA) with archived data from the Ngorongoro Conservation Area Authority (NCAA). We found that most (71\%) pastoralists were aware of general climate change impacts, rainfall variability, and impacts of extreme events on their livestock. Most (> 75\%) respondents perceived erratic and reduced amounts of rainfall, prolonged and frequent periods of drought as the main climate change challenges. Mean annual rainfall accounted for only $46 \%$ $\left(R^{2}\right),(p=0.076)$ and $32 \%\left(R^{2}\right),(p=0.22)$ of cattle, and sheep and goat population variability, respectively. Unexpectedly, cattle losses intensified by $10 \%$ when herd size increased $(p<0.001)$ and by $98 \%(p=0.049)$ when mobility increased, implying that increasing herd sizes and mobility do not cushion households against climate change shocks. Our study highlights the need to enhance adaptive capacity of the pastoralist communities through interventions that proactively reduce vulnerability. We recommend that future research should address the profitability of pastoral cattle production under changing environmental conditions.
\end{abstract}

Keywords Climate variability · Pastoralist perceptions · Rangelands · Eastern Africa · Adaptive capacity

\section{Introduction}

Rainfall strongly influences human life styles and land use patterns [1, 2]. As such, areas receiving at least $700 \mathrm{~mm}$ of annual average rainfall are likely to be dominated by rain-fed agricultural activities, whereas areas with low and/or highly variable rainfall regimes are dominated by pastoralism as the main livelihood strategy [3]. The rural underprivileged pastoralists in developing countries are, therefore, the most exposed to the effects of climate change and rainfall variability [4]. In East Africa, rainfall variability has evident wide ranging effects and its devastating impacts are agreed upon by researchers and policy makers, while the extent of exposure differs locally $[5,6]$.

As rainfall becomes more variable, plant tissues increasingly lignify, have lower digestibility [7], and change in

\footnotetext{
Supplementary Information The online version contains supplementary material available at (https://doi.org/10.1007/s42452-020-04111 $-0)$.

Cecilia M. Leweri, cecilia.leweri@tawiri.or.tz|'Department of Sustainable Agriculture, Biodiversity and Ecosystem Management, School of Life Sciences and Bio-Engineering, The Nelson Mandela African Institution of Science and Technology, P.O. Box 447, Arusha, Tanzania. ${ }^{2}$ Tanzania Wildlife Research Institute (TAWIRI), P.O. Box 661, Arusha, Tanzania. ${ }^{3}$ Wildlife Division, Ministry of Natural Resources and Tourism, P.O. Box 1351, 40472 Dodoma, Tanzania. ${ }^{4}$ Hans Ruthenberg Institute, Ecology of Tropical Agricultural Systems, University of Hohenheim, Garbenstr. 13, 70599 Stuttgart, Germany.
} 
composition towards less palatable species [8]. These shifts may lead to land cover/land use changes that comprise less favourable compositions of animal forage species, making it more difficult for smallholders to manage feed deficits in the dry season [9]. Livestock die offs have become increasingly common $[9,10]$, which implies the necessity of an in-depth study on the effects of rainfall variability on traditional cattle pastoralism and household food security.

For many years, pastoralists have diversified their herding strategies and management techniques to cope with climate and environmental dynamics [11]. They have diversified their livestock species, expanded grazing/browsing sites to larger areas and rotated the use of dry and wet season pastures [12]. In addition, pastoralist families usually comprise many members to provide labour for facilitating herd mobility [13]. Furthermore, pastoralists maintain large herds to ensure that sufficient animals survive to rebuild the herds after drought [14]. However, this combination of adaptation strategies has become constrained by a number of factors, including an increasing human population along with a stable/declining livestock population and a decreasing rangeland area available $[15,16]$.

The Ngorongoro Conservation Area (NCA) is a multiple land use area, established in 1959, encompassing both wildlife conservation and economic development of resident Maasai pastoralists in Tanzania [17]. The NCA illustrates, on a rather small scale, many of the biological constraints and responses characterizing rangelands and pastoralism in East Africa, balancing the competing needs of its multiple users [18]. The NCA is currently facing climate change-driven challenges [19], high human population growth rates [20], and wild life-livestock competition attributed to localized overgrazing [21]. A large proportion of the NCA is semi-arid, with an average annual rainfall of less than $500 \mathrm{~mm}$; hence, grassland productivity is low and the risk of overgrazing and death from starvation is high [22].

We wanted to (1) document the perception of the NCA pastoralists towards rainfall variability and its impacts on their traditional pastoral livelihoods and rangeland conditions. Further, we (2) explored the trends in livestock production and herd sizes to portray rainfall variability as one of the drivers of livestock dynamics; and, (3) analysed the drought adaptation strategies in NCA pastoralists. We expected that pastoralists will perceive reduced lengths of rainfall seasons and more frequent droughts as the main indicators of rainfall variability [23]. Furthermore, drought incidents will be reflected by massive cattle die off, but will be less visible for sheep and goats, similar to what has been recorded in Ethiopia [24] and South Africa [25]. We also expected that the mean livestock mortality rates will decrease with intervention measures (supplemental food and mobility) [26] and demographic variables (herd and household size) [13].

\section{Materials and methods}

\subsection{Study area}

We conducted this study in four wards of the Ngorongoro Conservation Area (NCA) in northern Tanzania, $3^{\circ} 14^{\prime}$ 29.56" S and 35 $29^{\circ} 16^{\prime \prime}$ E, a UNESCO World Heritage Site, predominantly inhabited by the Maasai pastoralists [27]. Rainfall in NCA is highly seasonal and variable, with the eastern slopes of the crater highlands receiving annual averages of about $1200 \mathrm{~mm}$, which decreases to about $800 \mathrm{~mm}$ in the midlands and further to $400 \mathrm{~mm}$ on the plains of the lowlands [22]. Traditionally, the Maasai are semi-nomadic pastoralists and their main economic activities in the NCA are livestock keeping and tourism [28]. The livestock species included cattle (Bos taurus), goat (Capra aegagrus hircus), and sheep (Ovis aries) [29]. The four wards (Fig. 1) were selected based on elevation and variations in rain intensity and, hence, rangeland productivity; Endulen (Midland), Nainokanoka (Highland), Olbalbal (Lowland), and Ngorongoro (Midland) [29].

\subsection{Data collection}

Data collection involved (1) participatory discussions (2) household surveys using semi-structured interviews [30] and (3) acquisition of long-term rainfall data of the study area, covering monthly and average annual rainfall $(\mathrm{mm})$, recorded at the Ngorongoro Conservation Area Authority (NCAA) Headquarters, from the years 1967-2018. Participatory Rural Appraisal (PRA) meetings were conducted in each of the four wards with eight to twelve participants [31] in March, 2018, to elicit information on the understanding and perception of village leaders/elders and livestock officers about the trends in climate incidents (particularly rainfall events) over the last ten years. In addition, we asked about perceived changes in rangeland condition, grazing mechanisms/initiatives to adapt to changing rainfall patterns and the interest and influence in conservation initiatives by different groups. All participants were formally invited by the Ward Executive Officers (WEO) in advance of the group meetings. A checklist was used to facilitate the discussions. All discussions were conducted in Kiswahili language, audio-taped and transcribed into English.

We further administered 241 household questionnaires across the four wards between March and June, 2018. The household surveys were conducted by the researcher and two local research assistants, who had been trained 
Fig. 1 Map of Ngorongoro Conservation Area in Northern Tanzania showing the four wards selected for this study

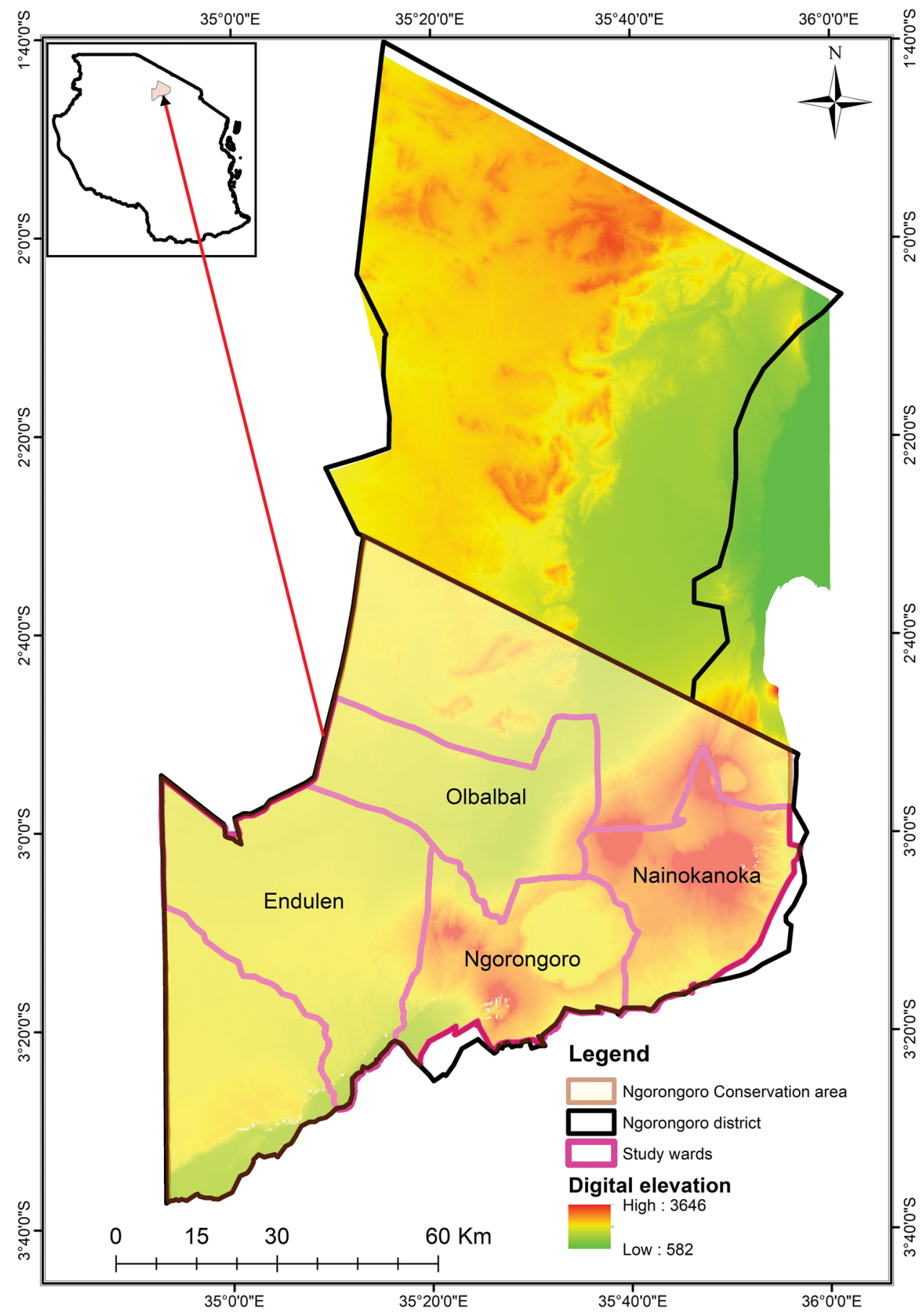

livestock numbers and constraints to livestock production. We further asked about herd mobility and intervention measures taken to reduce the impact of droughts and associated livestock mortalities.

\subsection{Statistical analyses}

Descriptive analysis for the structured (closed) household questionnaire was performed using frequency tables. Using 
the rainfall data, the Standardized Precipitation Index (SPI) was calculated using the SPI package in R version 3.1.6 [32]. This index reflects the number of standard deviations, by which the observed cumulative rainfall departs from the long-term mean and is considered an appropriate method for monitoring droughts in East Africa [33]. Monthly precipitation time series were also aggregated annually and in monthly trimesters as December-January-February, March-April-May, June-July-August, and September-October-November, which correspond to short dry, long rain, long dry, and short rainy season, respectively, to observe potential changes at the seasonal scale. HydroTSM package [34] in Rstudio was used because of its capability functions in the management, analysis, interpolation, and plotting of time series from daily and monthly data.

Livestock production was analysed from the number of livestock owned by households and complemented by livestock data based on NCAA archived data spanning from the years 1967-2017. We assessed the change in proportion between cattle and sheep and goats over that time period. To quantify the different livestock types and sizes, the Tropical Livestock Unit (TLU) was used, with $1 \mathrm{TLU}=$ one cow with a body weight of $250 \mathrm{~kg}$. The commonly used TLU in eastern Africa is cattle $=0.7$, sheep $=0.1$, goat $=0.1$, pig $=0.2$ and chicken $=0.01$ [35]. Regression analysis in Minitab was used to determine associations between livestock populations and rainfall variability.

A logit model was used to identify factors influencing cattle deaths during the 2015-2016 dry period using the variables "number of cattle owned before drought", "supplemental feeds" and "household size";

$\log \left[P_{i j} /\left(1-P_{i j}\right)\right]=\gamma_{0}+\gamma_{1} x_{1 j}+\gamma_{2} x_{2 j}+\gamma_{3} x_{3 i j}$

where $P_{i j}$ is the probability of death of cattle in a herd belonging to the $j$ household $\left(P_{i j}=1\right.$ for death observation and 0 otherwise), $\gamma_{0}$ is the intercept, $\gamma_{1}$ to $\gamma_{5}$ are regression coefficients, $x_{1 j}$ is the pre-drought cattle herd size, $x_{2 j}$ is the family size, $x_{3 j}$ is feed supplementation $\left(x_{3 j}=1\right.$ for supplemented herds and 0 otherwise). For herds that experienced mortalities during a drought, mortality rate was calculated as the number of dead cattle divided by the number of cattle owned before the drought year. A generalized linear model (GLM) with Poisson distribution was further used to identify factors influencing variation in mortality rate.
Table 1 The proportion (\%) of pastoralists that perceived changes in climate and rangeland condition in the Ngorongoro Conservation Area (NCA) ecosystem over the last 10 years $(n=241)$

\begin{tabular}{lclc}
\hline Variable & Decrease & Increase & No change \\
\hline Climatic conditions & 4 & 79 & 17 \\
Precipitation & 61 & 11 & 28 \\
Length of rainy season & 15 & 21 & 64 \\
Flood occurrences & 16 & 76 & 8 \\
Drought occurrences & & & \\
Rangeland condition & 14 & 63 & 23 \\
Time spent for finding good & & & \\
$\quad$ grazing land & 50 & 30 & 20 \\
Availability of grazing land & 60 & 21 & 19 \\
Grassland vegetation cover & 60 & 34 & 4 \\
Grass species diversity & 62 & 73 & 23 \\
Shrubland cover & 3 & & \\
\hline
\end{tabular}

\section{Results}

\subsection{Rainfall patterns and variability}

The study area had a bimodal rainfall characteristic with mean $( \pm S D)$ monthly rainfall of $73.5 \pm 84.3 \mathrm{~mm}$ over the years from 1967 to 2018 (Fig. SI1). The Standardized Precipitation Index (SPI) showed prolonged periods of moderate dry weather $(-1.29 \leq \mathrm{SPI}<-0.80)$ recorded in 1995/1996 and $2015 / 2016$ and exceptionally dry weather $(\mathrm{SPI}<=-2)$ recorded in between 1991 and 1998 and between 2012 and 2016 (Fig. SI2). The mean precipitation varied from 0 to $>300 \mathrm{~mm}$ per season over the study period (Fig. SI3). The highest annual mean precipitation ( $\geq 300 \mathrm{~mm}$ ) was recorded in the long rainy season of the year 1983, and similar amounts were recorded in 1997 during the El Niño effect. The short rainy season had its highest mean precipitation $(150 \mathrm{~mm}$ ) in 1969, which happened only once in the entire period of 50 years, while the period between 2015 and 2016 presented instances of lowest values of precipitation. Hence, rainfall variability occurred within the season, from season to season, and from year to year.

\subsection{Herders' perception on rainfall variability and rangeland condition}

More than two-thirds (71\%) of the respondents were aware of recent changes in rainfall patterns and increased frequency of droughts, floods, and disease outbreaks. They identified human land-use activities such as deforestation, desertification, and improper grazing practices as the main factors impacting rangelands. Majority (79\%) of pastoralists claimed that the amount of rain per season has increased over the last ten years, but rainfall events had become more unpredictable and shorter in duration 
as summarized in Table 1. Most respondents (76\%) also perceived an increase in drought frequencies.

About two-thirds, i.e. $63 \%$, and $73 \%$ of the 241 respondents, mentioned that they need more time for finding good grazing areas and that shrubland cover has increased over the last ten years, respectively. More than half $(50 \%$, $60 \%$, and $62 \%$ ) of the respondents mentioned a decrease in availability of grazing land, grass cover, and grass species diversity, respectively. Drought was mentioned as the likely cause of decrease in grazing land by $21 \%(p=0.01)$, while the remaining factors such as increase in human and livestock population remained less important.

\subsection{Livestock production}

All 241 surveyed households owned some livestock, the mean ( \pm SD) TLU owned per household was $28 \pm 21$ but varied from 3 to 140 TLU (Table SI1). In particular, 68\% of pastoralists mentioned cattle as the most vulnerable livestock type, that the number of cattle per household has been declining, and that cattle were generally in poor condition. Despite of the recurrent rainfall variability, the proportion of sheep and goats has increased by $54 \%$ and $63 \%$, respectively (Fig. 2), highlighting the preference by pastoralists to own smaller livestock types.

Our NCAA archived records showed that the number of cattle was about 161,034 , whereas the number of sheep and goats was 100,689 at the time of establishment of NCA in 1960s, summing up to a TLU of 79,617 and a per capita TLU of 10. The observed decreasing trend of TLU is mainly associated with the increase in human population, which has further reduced the TLU to 1 in the year 2016. Moreover, we found that from the time of establishment of NCA, there has been an overall steady increase in the number of people $\left(R^{2}=0.96, p<0.001\right)$, sheep and goats $\left(R^{2}=0.71\right.$,

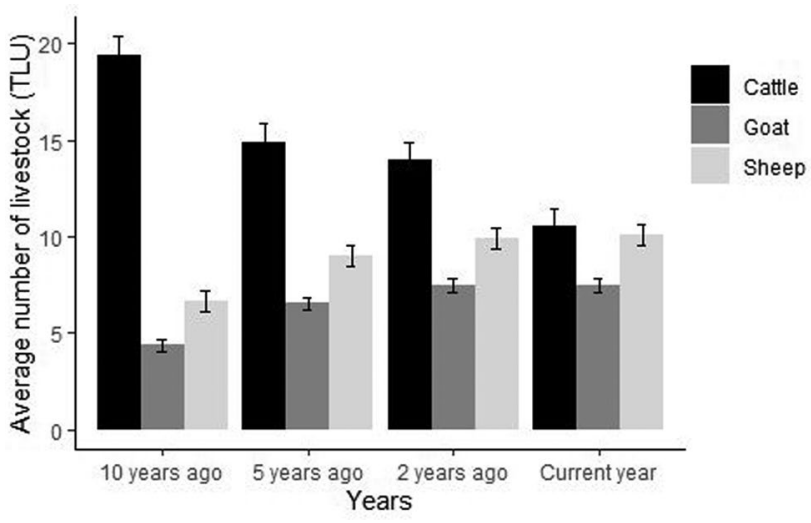

Fig. 2 Average $( \pm S E)$ number of livestock owned per household in the surveyed villages of the NCA over the last 10 years (based on interviews). Livestock is based on TLU (1 TLU = one cow with a body weight of $250 \mathrm{~kg}$ ) $p=0.002)$ and cattle $\left(R^{2}=0.55, p=0.028\right)$, whereas the TLU per capita steadily decreased $\left(R^{2}=-0.7, p<0.003\right)$, (Fig. SI4).

\subsection{Effects of rainfall variability on livestock population and mortality}

The mean annual rainfall of NCA accounted for only $46 \%$ $(p=0.076)$ and $32 \%(p=0.22)$ of cattle, and sheep and goat population variability, respectively. Moreover, during the 2015/2016 drought occurrences, 112 herds (47\%) of the interviewed 241 pastoralists experienced cattle losses. The likelihood of cattle death occurrences increased by $10 \%$ $(p<0.001)$ and $98 \%(p=0.049)$ with an increase in number of cattle in the herd and increased mobility, respectively (Table 2). Mortality rate barely decreased, by $2 \%(p=0.116)$ and $2 \%(p=0.697)$ with increasing number of cattle in the herd and household size, respectively. Feeding cattle with supplementary feeds and mobility did not significantly reduce the odds of death occurrences, i.e. by $22 \%(p=0.57)$ and $15 \%(p=0.76)$, compared to those receiving no feed supplementation (Table 2). It was difficult to quantify the amounts of the different feed types purchased and to assess their sufficiency for the target animals because pastoralists have no tendency of keeping records of livestock feeds.

\section{Discussion}

We found that pastoralists were aware that climate change and variability is happening in their local areas and the impacts were felt in their major form of livelihood strategy. Similarly, the PRA discussions (Annex 1) revealed that declines in amounts of rainfall, delayed rainfall starting points, and early cessation of rainfall have become more frequent within the last decade. Similar perceptions were reported by pastoralists in other semi-arid rangelands [36-38] as well as by farmers in the southern highlands of Tanzania, western and southern Africa [39-41]. Respondents admitted that frequent droughts have led to severe economic impacts associated with poor livestock markets and claimed that the price of cattle kept on declining due to poor health condition. Moreover, respondents reported that inadequate feed resources and water as well as heat stress has led to reductions in milk yield, which was also reported elsewhere in Tanzania [42]. Milk is a staple food for pastoralists, and a reduced supply may pose risks to food and nutritional security in these communities, in particular for women and children [11]. Hence, our study calls for improvements to adaptive capacity of pastoralist communities, including effective and sustainable animal health services. 
Table 2 Factors affecting death occurrence and extent of mortality rate in cattle herds for the year 2015/2016

\begin{tabular}{|c|c|c|c|c|c|}
\hline \multirow[t]{2}{*}{ Predictor variables } & \multirow[t]{2}{*}{ Mean $^{a}$} & \multicolumn{2}{|c|}{ Death occurrence $^{b}$} & \multicolumn{2}{|c|}{ Mortality rate ${ }^{c}$} \\
\hline & & Odds ${ }^{\mathrm{e}}$ ratio & $P$ & $\begin{array}{l}\text { Estimated } \\
\text { coefficients }\end{array}$ & $P$ \\
\hline Number of people $\mathrm{HH}^{-1}$ & 7.7 & -0.003 & 0.966 & -0.022 & 0.697 \\
\hline Pre-drought cattle numbers $\mathrm{HH}^{-1}$ & 20.4 & 0.101 & $<0.001$ & -0.021 & 0.116 \\
\hline Feed supplement (yes/no) $)^{\mathbf{d}}$ & & 0.182 & 0.691 & 0.219 & 0.576 \\
\hline Mobility (yes/no) ${ }^{d}$ & & 0.984 & 0.049 & 0.148 & 0.762 \\
\hline
\end{tabular}

Death occurrence based on the full number of surveyed households $(n=241)$. Mortality rate based on the number of households that experienced deaths $(n=112), \mathrm{HH}=$ household

${ }^{a}$ Mean for quantitative variable

${ }^{\text {b}}$ Presence or absence of death

'Proportion of number of deaths at household level to pre-drought herd size

${ }^{\mathrm{d}}$ Dummy (indicator) variables

e Odds ratio greater than 1 indicates that death is more likely to occur, and an odds ratio less than 1 indicates that death is less likely to occur

\subsection{Climate variability information}

The concept of 'climate change' was associated with variability in weather parameters, the major concern being erratic, and unpredictable rainfall, which is a typical pattern of conception in communities living in arid areas [10]. Analysis of rainfall data collected from NCAA headquarters shows a slight overall decline in rainfall over the years from 1967 to 2018. Moreover, pastoralists were able to recall years, in which they experienced severe water and pasture shortages, which correlated with NCAA rainfall data, i.e. two incidents aligned with years of low total precipitation and/or extended periods of moderate droughts, as indicated by the SPI and the time series of seasonal precipitation. A decline in overall rainfall and increased variability is a current concern over a wide range of similar communities across Africa and has been reported in other regions of Tanzania and eastern Africa $[42,43]$. This condition has severely impacted availability of water and pasture and is likely to lead to conflicts over rangeland resources between pastoralists and wildlife management authorities, as was reported in Monduli [44], Kilombero [45], Burunge [46] and many other places in Tanzania, where pastoralism represents the main livelihood basis.

\subsection{Impacts of climate change on livestock production}

Impacts of rainfall on livestock production have often been expressed as a drastic decline in livestock population in the years following drought incidents $[23,47]$. In our study, pastoralists reported that recurrent drought periods have caused massive losses of livestock, in particular cattle. Droughts have led to severe feed shortages and water scarcity, which leads to serious socio-economic impacts [48]. For example, Borana of Southern Ethiopia faced high cattle losses of up to $37 \%$ and $42 \%$ of all cattle during severe drought periods in 1983-1985 and 1991-1993, respectively [49]. Similarly, during the 2017's drought, NCAA reported to have lost 77,389 heads of cattle, 72,881 heads of goats and 78,490 heads of sheep [50], which, when compared with the livestock count of the previous year [51], translates into a total loss of about $70 \%$ of livestock. Further, droughts make animals more susceptible to infectious diseases, which reduces the ability of animals to survive [52]. Since these incidents occured concurrently with a severe drought, which was exacerbated by a shortage of forage for livestock and wildlife, we claim that climate change might be strongly determining livestock mortality.

In our study, sheep and goat populations were moderately associated with mean annual precipitation, reflecting that smaller livestock species can survive well during good conditions [53]. Generally, cattle are the most vulnerable livestock species due to higher energy requirements than other livestock types [54,55]. In addition, recovery of cattle populations can be prolonged by interruptions due to subsequent shocks (decline in population or disturbance in age and sex structure), which can occur under high rainfall variability [56]. Given the shorter periods between successive droughts that we observed, with an approximate interval of 4-6 years, it is unlikely that most cattle herds would have sufficient time to recover from shocks and increase to their pre-drought numbers [57].

Shifting from cattle pastoralism to multispecies herding has increased over time in response to climate change and variability $[58,59]$. In our study, sheep and goats have slightly increased over the period of 10 years, while the population of cattle has decreased. This was in agreement with reports by NCAA, where a steady shift from 
cattle towards small ruminant ownership was recorded, from about $8 \%$ of the TLUs in the 1960 s to $26 \%$ in the present decade. This trend indicates an active selection by pastoralists towards sheep and goats, particularly in times when they need income, as it is a reasonable economic but short-term strategy for quick asset building [60]. Moreover, studies on feeding ecology suggest that sheep and goats are better adapted to nutritionally poor vegetation than cattle [61], hence, are likely to survive on a stressed environment. Studies in other parts of Africa $[62,63]$ also reported that changes in climate are likely to drive selection of animal species towards those that can cope best with changed environmental conditions. Sheep are an increasingly dominant livestock species in NCA, which might further degrade the rangeland vegetation due to their feeding ecology [64]. Grazing by sheep selectively removes nutritious plants and continually reduces species diversity and abundance of most vascular plants and grasses, leading to an increase in herbs, sedges and shrubs $[65,66]$. Yet, the long-term impact of small stock grazing on this landscape is still uncertain, and appropriate grazing management will be required.

\subsection{Livestock wealth below subsistence levels}

Human population growth in NCA is estimated to be between 3 and 5\% per year [67], and we found that per capita livestock holdings across households at NCA varied strongly but often was less than 5 TLU per capita. Generally, 6 TLU per capita represents a minimum adequate income requirement for pastoralists in order to meet subsistence needs $[68,69]$. Below this threshold, herders must diversify their production base to provide enough food [70]. We conclude that in NCA, the majority (95\%) of the households do not own sufficient livestock to sustain themselves in the traditional way and must, therefore, look for alternative sources of income. This further suggests that the human population in the NCA should be reduced and the development of non-pastoral economic activities outside NCA enhanced in order to widen the range of income generating activities and investment options available. Studies in Maasai ranches around the Maasai Mara National Reserve (MMNR) in...? reported a similar fall in per capita livestock numbers, mainly attributed to human population growth, while livestock densities had either remained the same or decreased [69].

Pastoralists in East Africa apply different adaptation strategies to reduce the impact of drought on their livestock productivity, but their overreliance on livestock makes them highly vulnerable to climate shocks [71, 72]. In our study, 34\% of the interviewed 241 households had selectively supplemented weak and young animals with crop residues, straw and hay, which still could not significantly reduce death occurrences. This fact calls for an urgent need of education to pastoralists on the importance of supplementary livestock feeding [24]. Our respondents also claimed mobility as another strategy used to cope with drought, having adapted to the vegetation heterogeneity between mountaneous forest and grasslands, which influences forage availability for grazing animals in NCA [22]. This agrees with other studies on mobility in communal rangelands of Africa [73-75].

Despite being widely practiced across Africa, mobility needs to be well planned to avoid overgrazing, range degradation, and eventually increased livestock mortality $[76,77]$. A key drought retreatment strategy and an efficient way of rotational vegetation use shows an inverse relationship with mortality [13]. In contrast, our findings showed that large families did not suffer from fewer cattle losses than small families, which was also reported by Scoones [78] in Southern Zimbabwe. Moreover, in our study, large households corresponded strongly with larger herds, in which higher records of livestock deaths were inevitable. This shows that large herd sizes do not cushion households against climatic shocks, which is contrary to justifications made on the tendency by pastoralists to maximize herd sizes as a risk management strategy [79].

\section{Conclusion}

We found that climate variability is well understood among pastoral communities through their day to day experience and observations in NCA. Reduced rainfall and recurrent droughts were reported as major challenges to livestock production due to their impacts on pasture and water availability. Pastoralists responded to the changing environmental conditions by adjusting their herd composition towards more diverse livestock species, preferably to those with low biomass requirements. This trend underlines the need to enhance the adaptive capacity of pastoralist communities in Tanzania through interventions that proactively reduce vulnerability. Moreover, future research should address the profitability of pastoral cattle production under the changing environmental conditions.

Acknowledgements We are thankful to the African Development Bank for funding $\mathrm{CL}^{\prime}$ s research. Furthermore, we extend our gratitude to the Orskov foundation and Idea Wild for additional funds. We acknowledge the Tanzania Wildlife Research Institute (TAWIRI) and Ngorongoro Conservation Area Authority (NCAA) for granting us the research permit and access to conduct the field work.

Funding This study was funded by the African Development Bank (AfDB Grant Number 210015503281). 


\section{Compliance with ethical standards}

Conflict of interest On behalf of all authors, the corresponding author states that there is no conflict of interest.

Ethical approval An Ethical clearance was obtained from the research ethics committee at the Nelson Mandela African Institution of Science and Technology (NM-AIST), Tanzania and Tanzania Commission for Science and Technology (COSTECH). Verbal consent was further obtained from all participants as reflected by their willingness to be interviewed and attend and contribute to the meetings.

Open Access This article is licensed under a Creative Commons Attribution 4.0 International License, which permits use, sharing, adaptation, distribution and reproduction in any medium or format, as long as you give appropriate credit to the original author(s) and the source, provide a link to the Creative Commons licence, and indicate if changes were made. The images or other third party material in this article are included in the article's Creative Commons licence, unless indicated otherwise in a credit line to the material. If material is not included in the article's Creative Commons licence and your intended use is not permitted by statutory regulation or exceeds the permitted use, you will need to obtain permission directly from the copyright holder. To view a copy of this licence, visit http://creativecommons .org/licenses/by/4.0/.

\section{References}

1. Marchant R, Lane P (2014) Past perspectives for the future: foundations for sustainable development in East Africa. J Archaeol Sci 51:12-21

2. Reid RS, Fernández-Giménez ME, Galvin KA (2014) Dynamics and resilience of rangelands and pastoral peoples around the globe. Annu Rev Environ Resour 39:217-242

3. Ogutu JO, Piepho H-P, Dublin HT et al (2008) Rainfall influences on ungulate population abundance in the Mara-Serengeti ecosystem. J Anim Ecol 77:814-829

4. IPCC (2013) Climate change. In: Stocker TF, Qin D, Plattner GK et al (eds) The physical science basis: contribution of Working Group I to the fifth assessment report of the Intergovernmental Panel on Climate Change. Cambridge University Press, Cambridge, pp 1-1535

5. Omondi P, Awange JLL, Ogallo LAA et al (2012) Decadal rainfall variability modes in observed rainfall records over East Africa and their relations to historical sea surface temperature changes. J Hydrol 464-465:140-156

6. Williams PA, Funk C, Michaelsen J et al (2012) Recent summer precipitation trends in the Greater Horn of Africaand the emerging role of Indian Ocean sea surface temperature. Clim Dyn 39:2308-2328

7. Giridhar K, Samireddypalle A (2015) Impact of climate change on forage availability for livestock. In: Sejian V, Gaughan J, Baumgard L et al (eds) Climate change impact on livestock: adaptation and mitigation. Springer New Dehli, New Dehli, p 532

8. da Silveira Pontes L, Maire V, Schellberg J et al (2015) Grass strategies and grassland community responses to environmental drivers: a review. Agron Sustain Dev 35:1297-1318

9. Thornton PK, van de Steeg J, Notenbaert A et al (2009) The impacts of climate change on livestock and livestock systems in developing countries: a review of what we know and what we need to know. Agric Syst 101:113-127
10. Thornton PK, Ericksen $P$, Herrero $M$ et al (2014) Climate variability and vulnerability to climate change: a review. Glob Chang Biol 20:3313-3328

11. Opiyo F, Wasonga O, Nyangito M et al (2015) Drought adaptation and coping strategies among the Turkana Pastoralists of Northern Kenya. Int J Disaster Risk Sci 6:295-309

12. Galvin K, Thornton P, Mbogoh S (1997) Integrated modeling and assessment for balancing food security, conservation and ecosystem integrity in East Africa. Report, Socio-Economic Model Compon

13. Naess MW, Næss MW (2012) Cooperative pastoral production: reconceptualizing the relationship between pastoral labor and production. Am Anthropol 114:309-321

14. Mcpeak J (2005) Individual and collective rationality in pastoral production: evidence from Northern. Source Hum Ecol 33:171-197

15. Fratkin E (1997) Pastoralism: governance and development issues. Annu Rev Anthropol 26:235-261

16. Galvin KA (1992) Nutritional ecology of pastoralists in dry tropical Africa. Am J Hum Biol 4:209-221

17. Rodgers WA, Homewood KM (1986) Cattle dynamics in a pastoralist community in Ngorongoro, Tanzania, during the 1982-3 drought. Agric Syst 22:33-51

18. Boone RB, Coughenour MB, Galvin KA et al (2002) Addressing management questions for Ngorongoro Conservation Area, Tanzania, using the Savanna modelling system. Afr J Ecol 40:138-150

19. Galvin KA, Thornton PK, Boone RB et al (2004) Climate variability and impacts on east African livestock herders: the Maasai of Ngorongoro Conservation Area, Tanzania. Afr J Range Forage Sci 21:183-189

20. Masao CA, Makoba R, Sosovele H (2015) Will Ngorongoro Conservation Area remain a world heritage site amidst increasing human footprint? Int J Biodivers Conserv 7:394-407

21. Nina J (2000) Placemaking, pastoralism, and poverty in the Ngorongoro Conservation Area, Tanzania. In: Broch-due V, Schroeder RA (eds) Producing nature and poverty in Africa. Nordiska Afrikainstitutet, Stockholm, p 350

22. Niboye EP (2010) Vegetation cover changes in Ngorongoro Conservation Area from 1975 to 2000: the importance of remote sensing images. Open Geogr J 3:15-27

23. Kimaro EG, Mor SM, Toribio JALML (2018) Climate change perception and impacts on cattle production in pastoral communities of northern Tanzania. Pastoralism 8:1-16

24. Angassa A, Oba G (2013) Cattle herd vulnerability to rainfall variability: responses to two management scenarios in southern Ethiopia. Trop Anim Health Prod 45:715-721

25. Vetter S, Goodall VL, Alcock R (2020) Effect of drought on communal livestock farmers in KwaZulu-Natal, South Africa. Afr J Range Forage Sci 37:93-106

26. Coppock DL, Fernández-Giménez M, Hiernaux P et al (2017) Rangeland systems in developing nations: conceptual advances and societal implications. In: Briske DD (ed) Rangeland systems; processes, management and challenges. Cham, Springer Nature, pp 569-641

27. Homewood KM, Rodgers WA (1991) Maasailand ecology: pastoralist development and wildlife conservation in Ngorongoro, Tanzania. First. Cambridge University Press, Cambridge. Epub ahead of print 1991. https://doi.org/10.1017/cbo978051152556 8

28. Melita A, Mendlinger S (2013) The impact of tourism revenue on the local communities' livelihood: a case study of Ngorongoro Conservation Area, Tanzania. J Serv Sci Manag 6:117-126

29. McCabe JT (2003) Sustainability and livelihood diversification among Maasai of Northern Tanzania. Hum Organ 62:100-111 
30. Nyariki DM (2009) Household data collection for socio-economic research in agriculture: approaches and challenges in developing countries. J Soc Sci 19:91-99

31. Braun V, Clarke V (2013) Successful qualitative research; a practical guide for beginners, 1st edn. SAGE Publications Ltd, London

32. R Core Team (2018) R: a language and environment for statistical computing. R Foundation for Statistical Computing, Vienna. https://www.r-project.org/. Accessed 23 July 2019

33. Ntale HK, Gan TY (2003) Drought indices and their application to East Africa. Int J Climatol 23:1335-1357

34. Zambrano-Bigiarini M (2020) Tutorial for introductory analysis of daily precipitation data with hydroTSM, pp 1-9

35. FAO (2008) Climate change and food security: a framework document. http://rstb.royalsocietypublishing.org/conte $\mathrm{nt} / 360 / 1463 / 2139$

36. Sangeda AZ, Maleko DD, Mtengeti EJ (2013) Socio-economic and ecological dimensions of climate variability and change for agro-pastoral communities in central Tanzania. Livest Res Rural Dev 25:12

37. West CT, Roncoli C, Ouattara F (2008) Local perceptions and regional climate trends on the Central Plateau of Burkina Faso. L Degrad Dev 19:289-304

38. Debela N, Mohammed C, Bridle K et al (2015) Perception of climate change and its impact by smallholders in pastoral/ agropastoral systems of Borana, South Ethiopia. Springerplus $4: 1-12$

39. Thomas DSG, Twyman C, Osbahr H et al (2007) Adaptation to climate change and variability: farmer responses to intraseasonal precipitation trends in South Africa. Clim Chang 83:301-322

40. Kangalawe $M(2012)$ Food security and health in the southern highlands of Tanzania: a multidisciplinary approach to evaluate the impact of climate change and other stress factors. Afr J Environ Sci Technol 6:50-66

41. Mertz O, Mbow C, Reenberg A et al (2009) Farmers' perceptions of climate change and agricultural adaptation strategies in rural sahel. Environ Manag 43:804-816

42. Magita SY, Sangeda AZ (2017) Effects of climate stress to pastoral communities in Tanzania: a case of Mvomero District. Livest Res Rural Dev 29:1-6

43. Gebrechorkos SH, Hülsmann S, Bernhofer C (2019) Long-term trends in rainfall and temperature using high-resolution climate datasets in East Africa. Sci Rep 9:1-9

44. Kaswamila A (2009) Human-wildlife conflicts in Monduli District. Int J Biodivers Sci Manag 5:199-207

45. Bergius M, Benjaminsen TA, Maganga F et al (2020) Green economy, degradation narratives, and land-use conflicts in Tanzania. World Dev 129:1-13

46. Bluwstein J, Moyo F, Kicheleri R (2016) Austere conservation: understanding conflicts over resource governance in tanzanian wildlife management areas. Conserv Soc 14:218-231

47. Kariuki R, Willcock S, Marchant R (2018) Rangeland livelihood strategies under varying climate regimes: model insights from southern Kenya. Land 7:2-22

48. Megersa B, Markemann A, Angassa A et al (2014) Impacts of climate change and variability on cattle production in southern Ethiopia: perceptions and empirical evidence. Agric Syst 130:23-34

49. Desta S, Coppock DL (2002) Cattle population dynamics in the southern Ethiopian rangelands, 1980-97. J Range Manag 55:439-451

50. NDC (2017) Taarifa ya mifugo iliyokufa kutokana na Njaa katika Tarafa ya Ngorongoro. Unpublished source, Ngorongoro District Council
51. TAWIRI (2016) Wildlife, Livestock and Bomas census in the Serengeti Ecosystem, Dry Season, 2016. TAWIRI Aerial Survey Report, p 35

52. Haseeb A, Jonathan Y, de William AG et al (2019) Economic burden of livestock disease and drought in Northern Tanzania. J Dev Agric Econ 11:140-151

53. Mapiye C, Chimonyo M, Dzama K (2009) Seasonal dynamics, production potential and efficiency of cattle in the sweet and sour communal rangelands in South Africa. J Arid Environ 73:529-536

54. Seo SN, McCarl BA, Mendelsohn RO et al (2010) From beef cattle to sheep under global warming? An analysis of adaptation by livestock species choice in South America. Ecol Econ 69:2486-2494

55. Lesnoff M, Corniaux C, Hiernaux P (2012) Sensitivity analysis of the recovery dynamics of a cattle population following drought in the Sahel region. Ecol Model 232:28-39

56. Oba G (2001) The effect of multiple droughts on cattle in Obbu, northern Kenya. J Arid Environ 49:375-386

57. Godde C, Dizyee K, Ash A et al (2019) Climate change and variability impacts on grazing herds: insights from a system dynamics approach for semi-arid Australian rangelands. Glob Chang Biol 25:3091-3109

58. Megersa B, Markemann A, Angassa A et al (2014) Livestock diversification: an adaptive strategy to climate and rangeland ecosystem changes in Southern Ethiopia. Hum Ecol 42:509-520

59. Watson EE, Kochore HH, Dabasso BH (2016) Camels and climate resilience: adaptation in Northern Kenya. Hum Ecol 44:701-713

60. Hauck S, Rubenstein DI (2017) Pastoralist societies in flux: a conceptual framework analysis of herding and land use among the Mukugodo Maasai of Kenya. Pastoralism 7:1-30

61. Jáuregui BM, García U, Osoro K et al (2009) Sheep and goat grazing effects on three Atlantic heathland types. Rangel Ecol Manag 62:119-126

62. Rojas-Downing MM, Nejadhashemi AP, Harrigan T et al (2017) Climate change and livestock: impacts, adaptation, and mitigation. Clim Risk Manag 16:145-163

63. Seo SN, Mendelsohn R, Dinar A et al (2009) Adapting to climate change mosaically: an analysis of African livestock management by agro-ecological zones. BE J Econ Anal Policy 9:1-35

64. Gordon IJ (2003) Browsing and grazing ruminants: are they different beasts? For Ecol Manag 181:13-21

65. Marrs RH, Lee H, Blackbird S et al (2020) Release from sheepgrazing appears to put some heart back into upland vegetation: a comparison of nutritional properties of plant species in longterm grazing experiments. Ann Appl Biol 177:152-162

66. Milligan G, Rose RJ, Marrs RH (2016) Winners and losers in a long-term study of vegetation change at Moor House NNR: effects of sheep-grazing and its removal on British upland vegetation. Ecol Indic 68:89-101

67. Slootweg S (2018) Climate change and population growth in pastoral communities of Ngorongoro District, Tanzania. In: Handbook of climate change resilience. Springer, pp 1627-1645

68. Omri-Pack M (1998) Transformations in the Maasai economy and resource utilisation: Kisonkoin Northern Tanzania. In: Berger A (ed) Twice humanity: implications for local and global resource use. Nordic Africa Institute, Uppsala, pp 87-98

69. Lamprey RH, Reid RS (2004) Expansion of human settlement in Kenya's Maasai Mara: what future for pastoralism and wildlife? J Biogeogr 31:997-1032

70. Nkedianye D, Ogutu J, Said M et al (2019) Livestock-wealth inequalities and uptake of crop cultivation among the Maasai of Kenya and Tanzania. World Dev Perspect 14:1-10

71. Sangeda AZ, Malole JL (2014) Tanzanian rangelands in a changing climate: impacts, adaptations and mitigation. Net J Agric Sci 2:1-10 
72. Sherwood A (2013) Community adaptation to climate change: exploring drought and poverty traps in Gituamba location, Kenya. J Nat Resour Policy Res 5:147-161

73. Descheemaeker K, Oosting SJ, Homann-Kee Tui S et al (2016) Climate change adaptation and mitigation in smallholder croplivestock systems in sub-Saharan Africa: a call for integrated impact assessments. Reg Environ Change 16:2331-2343

74. Odadi WO, Fargione J, Rubenstein DI (2017) Vegetation, wildlife, and livestock responses to planned grazing management in an African pastoral landscape. L Degrad Dev 28:2030-2038

75. Pas A (2018) Governing grazing and mobility in the Samburu Lowlands, Kenya. Land 7:41

76. Nkedianye D, de Leeuw J, Ogutu JO et al (2011) Mobility and livestock mortality in communally used pastoral areas: the impact of the 2005-2006 drought on livestock mortality in Maasailand. Pastoralism 1:1-17
77. Sulieman HM, Elagib NA (2012) Implications of climate, land-use and land-cover changes for pastoralism in eastern Sudan. J Arid Environ 85:132-141

78. Scoones I (1992) Coping with drought: responses of herders and livestock in contrasting savanna environments in Southern Zimbabwe. Hum Ecol 20:293-314

79. Naess MW, Bårdsen B-J (2013) Why herd size matters-mitigating the effects of livestock crashes. PLoS ONE 8:1-7

Publisher's Note Springer Nature remains neutral with regard to jurisdictional claims in published maps and institutional affiliations. 